\title{
Adductor Muscle Injury Following TVT-0 Placement - Case Report
}

\author{
Miriam Lopian ${ }^{1 *}$, Anat Beck ${ }^{1}$, Ora Tarnavsky ${ }^{2}$ and Gil Levy ${ }^{1}$ \\ ${ }^{1}$ Department of Obstetrics and Gynaecology, Mayanei Hayeshua Medical Centre, Israel \\ ${ }^{2}$ Department of Radiology, Mayanei Hayeshua Medical Centre, Israel
}

Submission: March 20, 2017 ; Published: April 26, 2017

*Corresponding author: Miriam Lopian, Department of Obstetrics and Gynaecology, Maayanei Hayeshua Medical Centre, 17 Harav Povarski Street, BneiBrak, Israel, Tel: +972-58-667-3736; Email:Miriamlopian@gmail.com

Abstract

The TVT-0 approach has become one of the most common surgical procedure for repair of stress urinary incontinence. It is considered to have high rate of success. Reported complications are related to the blind passage through the obturator foramen with possible injuries to the anatomical structures in the inner aspect of the obturator foramen. This is the first published case report of Adductor muscle haematoma following placement of a Tension Free Vaginal Tape through the obturator route. This case contributes to the literature another possible complication associated with the placement of a TVT-O.

Keywords: Haematoma; Adductor muscle; Stress urinary incontinence; TVT-0; Mid-urethral sling

Abbreviations: TVT-0: Tension Free Vaginal Tape-Obturator Route; TVT classic: Tension Free Vaginal Tape-Retropubic Route, COPD: Chronic Obstructive Pulmonary Disease; CTPA Computerised Tomography Pulmonary Angiogram; SUI: Stress Urinary Incontinence

\section{Introduction}

Urinary incontinence is an increasingly common problem that has a detrimental impact on the quality of life of millions of people worldwide. In women, up to $50 \%$ of incontinence is attributed to stress urinary incontinence (SUI) [1].

The insertion of a mid-urethral slinge. g. TVT (Tension Free Vaginal Tape) has become a popular solution to this problem. This procedure is considered as the gold standard for the treatment of female stress incontinence. The most widely used technique involves inserting the mid urethral sling through the obturator foramen (TVT-0) rather than the original technique which entered the retro-pubic space. The TVT-O achieves an overall cure rate of up to $90 \%[2,3]$. Complications are rare but include mesh erosion, infection, bleeding, neuropathy, bladder or urethral injury and pain [4].

Here we describe the first reported case in the literature of the formation of an intramuscular haematoma in the adductor muscle requiring blood transfusion following insertion of a TVT-O using the inside out technique.

\section{Case Report}

An 82-year-oldfemale was referred to our clinic with pelvic organ prolapse accompanied by urge incontinence, frequency and nocturia which had been treated sub-optimally with a ring pessary. She had well controlled Hypertension and COPD and her obstetric history includes 15 vaginal deliveries.

On physical examination she was found to have a 3rd degree vaginal vault prolapse with the cervix at $+5 \mathrm{~cm}$ beyond the introitus. Urodynamic testing revealed stress urinary incontinence at $260 \mathrm{ml}$ after reduction of the prolapse and her post void residual volume was normal.

The patient was scheduled for partial colpocleis and placement of a transobturator tape. The operation was performed under regional analgesia without any immediate complications. The procedure was uneventful with minimal blood loss.

On the first post-operative day, the patient became hypoxic and complained of chest pain. A CTPA revealed a small pulmonary venous filling defect and atelectas is. Treatment for suspected Pulmonary Embolism was initiated with $60 \mathrm{mg}$ of Enoxaparin twice a day.

On post-operative day 6 , she complained of pain in her left leg. On examination, a haematoma was noted on the inferiomedial and lateral aspect of her left thigh (Figures 1 \& 2). Her haemoglobin levels dropped from $10.3 \mathrm{~g} / \mathrm{dl}$ post operatively to $7.1 \mathrm{~g} / \mathrm{dl}$. Given the profound drop in haemoglobin levels, a 
CT was performed which revealed a $5 \times 6$ cmhaematoma within the left adductor magnus muscle (Figure 3). The patient was hemodynamically stable, her coagulation profile was normal and there was no radiographic evidence of active bleeding.
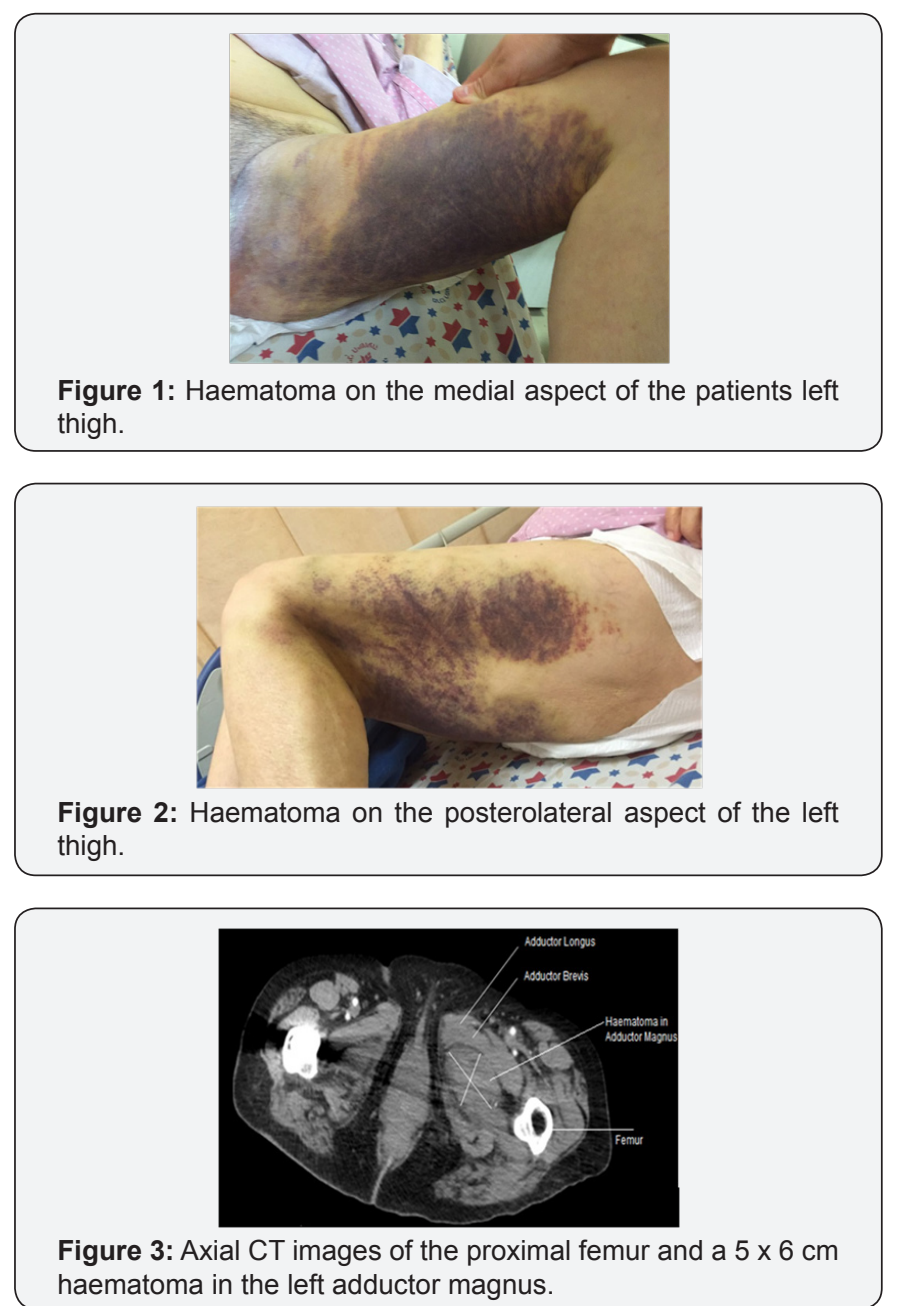

We discontinued Enoxaparin treatment and the patient received 2 units of packed red cells. The TVT remained in place. The haematoma resolved without requiring any surgical intervention. The rest of her recovery was unremarkable and she was discharged home on post-operative day 14 .

\section{Discussion}

The TVT-O is a safe, effective, minimally invasive and relatively low risk solution to a problem that has a significant impact on the quality of life of many women world-wide.

The original TVT procedure was described by Ulmsten in 1996 and involves passing the TVT through the retropubic space [5]. This technique was associated with an up to $6 \%$ rate of bladder injury [6] and requires intra operative cystoscopy. The transobturator approach (TVT-0) was developed to reduce this risk of bladder and neurovascular injury by avoiding the passage of the needles through the retropubic space. Indeed, many randomised controlled studies have demonstrated lower rates of complications bladder injury using the transobturator approach whilst at the same time maintaining similar cure rates $[7,8]$.
De Leval described the technique used for the inside out placement of the TVT-0 in 2003 [9]. A suburethral incision is made and a tract is created from the incision at the midurethral vaginal mucosa to the obturator foramen, close to the is chio-pubic ramus. The trocar passes through the tract and the obturator foramen medially, avoiding the obturator canal. The trocar and tape pass through the adductor muscles and subcutaneous tissues and exits through the skin. The tape is adjusted to be tension free and is cut close to the skin [10-12].

Research on cadavers demonstrates that the trocar and tape pass through the following structures: obturator internus, the obturator foramenan obturator externus, adductor brevis and gracilis (adductor) muscles [9-11].

Considering the proximity of the adductor brevis to the adductor magnus muscles, we cannot rule out the possibility of trocar passage through the magnus muscle along with the adjacent anatomical structures as a possible explanation for the haematoma location.

Using the inside out technique the needle passes on average $2.5 \mathrm{~m}$ from the obturator artery [10], $1.5 \mathrm{~cm}$ inferior-medial to the obturator canal, $1.6 \mathrm{~cm}$ from the anterior branch of the obturator nerve and $0.7 \mathrm{~cm}$ away from the posterior branch [11].

These studies demonstrate that, despite the blind passage of the trocar and the inevitable variation of its' precise trajectory, using the inside out technique, the transobturator tape never extends beyond the perineum, and entirely avoids the abdominal and pelvic cavities. This means that perforation of the epigastric vein and external iliac vessels as well as the bladder very rarely occur using the transobturator route [10].

Despite the more favorable route of passage, there are occasional vascular injuries attributed to the TVT-O. Cho et al. [13] recently reported 2 cases of significant arterial bleed ingrequiring embolization after TVT-O placement. One haematoma was from the upper vaginal branch of the internal iliac artery and the other haematoma was originated from the pubic branch of the obturator artery and inferior epigastric artery. There have also been reports of injury and bleeding from the uterine artery requiring embolization [14,15]. Less significant bleeds including a vulvar haematoma [16] and 3 retropubic haematomas managed conservatively $[17,18]$ have also been reported.

All vascular injuries reported following the transobturator sling placement have been located in the medial aspect of the obturator foramen. This report describes vascular injury at the level of the adductor muscles, at the lateral aspect of the obturator foramen which was caused by adductor muscle injury. Furthermore, most reports of haemorrhagic complications have been either intra operative or on the first post-operative day. Our patient started to show signs of a haematoma on post-operative day 4 . We believe that the patient had adequate haemostas is post operatively of small trocar injury to the adductor muscles and that the initiation of anticoagulation treatment disrupted 
haemostas is and allowed for a haematoma of such magnitude to form. Whilst there have been several reports of intramuscular infection [19-21] as a result of TVT-0 placement, this is the first case to demonstrate an intramuscular haematoma as a result of TVT-O placement.

\section{Summary}

This case is the first report of intramuscular bleeding following TVTO placement. This case also serves as a reminder that whilst TVT-O placement is deemed safe and relatively low risk, its use in an elderly population who are likely to have multiple co-morbidities might be more susceptible to its complications.

\section{References}

1. Reynolds W, Roger S, Dmochowski R, David F (2011) Epidemiology of stress urinary incontinence in women. Current Urology Reports 12(5): 370.

2. Nitti VW (2012) Complications of midurethral slings and their management. Canadian Urological Association Journal 6(5 Suppl 2): S120-S122.

3. Giacomo N, Ficarra V, Boscolo-Berto R, Secco S, Cavalleri S, et al. (2007) Tension-free midurethral slings in the treatment of female stress urinary incontinence: A systematic review and meta-analysis of randomized controlled trials of effectiveness. European Urology 52(3): 663-679.

4. Boyles SH, Edwards R, Gregory W, Clark A (2007) Complications associated with transobturator sling procedures. International Urogynecology Journal 18(1): 19-22.

5. Ulmsten UlF, Henriksson L, Johnson P, Varhos G (1996) An ambulatory surgical procedure under local anesthesia for treatment of female urinary incontinence. International Urogynecology Journal 7(2): 8186.

6. Piet H, Robinson D, Cardozo L, Bidmead J (2002) TVT: Trouble-free vaginal tape. Int Urogynecol J Pelvic Floor Dysfunct 13(Suppl 1): S31.

7. Pallavi LM, Singh P, Foon R, Toozs-Hobson P (2010) Two routes of transobturator tape procedures in stress urinary incontinence: A metaanalysis with direct and indirect comparison of randomized trials. BJU International 106(1): 68-76.

8. Jonathan SP, Lowder JL, Jones KA, Smith KJ (2010) Retropubic and transobturatormidurethral slings: A decision analysis to compare outcomes including efficacy and complications. International Urogynecology Journal 21(7): 787-793.

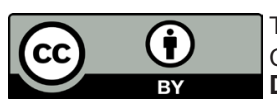

This work is licensed under Creative Commons Attribution 4.0 Licens DOI:_10.19080/JGWH.2017.03.555634
9. de Leval J (2003) Novel surgical technique for the treatment of female stress urinary incontinence: Transobturator vaginal tape inside-out. European Urology 44(6): 724-730.

10. Christl R, Kirschniak A, Drews U, Wallwiener D (2006) Transobturator vaginal tape inside-out: A minimally invasive treatment of stress urinary incontinence: Surgical procedure and anatomical conditions. Eur J Obstet Gynecol Reprod Biol 127(1): 123-129.

11. Piet H, Vanormelingen L, Roovers JP, de Jonge E, Smajda S (2007) Anatomical variability in the trajectory of the inside-out transobturator vaginal tape technique (TVT-0). Int Urogynecol J Pelvic Floor Dysfunct 18(10): 1201-1206.

12. Pierre B, Waltregny D, Reul O, Leval JD (2005) Transobturator vaginal tape inside out for the surgical treatment of female stress urinary incontinence: Anatomical considerations. J Urol 173(4): 1223-1228.

13. Eun-Ji C, Kim JB, Park SY, Kim SH, Kim CH, et al. (2016) Pelvic artery embolization in the management of pelvic arterial bleeding following midurethral sling surgery for stress urinary incontinence. Obstetrics \& Gynecology Science 59(2): 163-167.

14. Hyun PJ, Choi HS, Park JW, Lee BI, Cho SG (2008) Uterine artery embolization for the management of uterine artery bleeding after transobturator tape operation: A case report. Korean Journal of Obstetrics and Gynecology 51(12): 1567-1570.

15. Hoe KC, Lee JS, Kim JH (2009) A case using uterine artery embolization for the patient with uterine artery bleeding after transobturator tape operation. Journal of the Korean Continence Society 13(2): 173-176.

16. Richards SR, Balaloski SP (2006) Vulvar hematoma following a transobturator sling (TVT-0). Int Urogynecol J Pelvic Floor Dysfunct 17(6): 672-673.

17. Sujatha R, Kohli N (2005) Retropubic hematoma after transobturator sling procedure. Obstet Gynecol106 (5 Part 2): 1199-1202.

18. Ziad A, Reich A, Rudge A, Kreienberg R, Flock F (2008) Haemorrhage and nerve damage as complications of TVT-O procedure: Case report and literature review. Arch Gynecol Obstet 277(2): 161-164.

19. DeSouza R, Shapiro A, Westney OL (2007) Adductor brevis myositis following transobturator tape procedure: A case report and review of the literature. Int Urogynecol J Pelvic Floor Dysfunct 18(7): 817-820.

20. Goldman HB (2006) Large thigh abscess after placement of synthetic transobturator sling. Int Urogynecol J Pelvic Floor Dysfunct 17(3): 295296.

21. Johnson DW, El Hajj M, OBrien-Best EL, Miller HJ, Fine PM (2003) Necrotizing fasciitis after tension-free vaginal tape (TVT) placement. Int Urogynecol J Pelvic Floor Dysfunct 14(4): 291-293.

\begin{tabular}{l} 
Your next submission with Juniper Publishers \\
will reach you the below assets \\
- Quality Editorial service \\
- Swift Peer Review \\
- Reprints availability \\
- E-prints Service \\
- Manuscript Podcast for convenient understanding \\
- Global attainment for your research \\
- Manuscript accessibility in different formats \\
( Pdf, E-pub, Full Text, Audio) \\
- Unceasing customer service \\
Track the below URL for one-step submission \\
https://juniperpublishers.com/online-submission.php \\
\hline
\end{tabular}

